\title{
Role of Amino Acids and Endogenous Protein in the Germination of Mucor racemosus Sporangiospores
}

\author{
By MATTHEW L. TRIPP' ${ }^{1}$ AND JOHN L. PAZNOKAS ${ }^{1,2 *}$ \\ Departments of Bacteriology and Public Health ${ }^{1}$ and Basic Medical Sciences ${ }^{2}$, Washington \\ State University, Pullman, Washington 99164, U.S.A.
}

(Received 12 February 1981; revised 30 June 1981)

\begin{abstract}
The role of amino acids as triggers of Mucor racemosus sporangiospore germination was investigated. No single amino acid was as effective as glucose or peptone at triggering germination. Germination induced by glucose or peptone was $\mathrm{pH}$-independent, whereas germination induced by glutamate was $\mathrm{pH}$-dependent. The composition of the free amino acid pools of $\mathbf{M}$-spores (those unable to germinate on glutamate) was qualitatively and quantitatively similar to that of $\mathrm{C}$-spores (those capable of germinating on glutamate) with the exceptions of hydroxyproline and methionine whose concentrations were several-fold higher in C-spores. Glutamate and leucine were taken up by germinating and nongerminating spores; however, significant protein synthesis occurred only in germinating spores. Spores not triggered by 3-O-methyl-D-glucose (M-spores) contained about one-half the protein of those triggered by 3-O-methyl-D-glucose (C-spores). $\mathrm{C}$-spores initiated to germinate by 3-O-methyl-D-glucose decreased in total organic carbon and protein over a $6 \mathrm{~h}$ period; removal of the 3-O-methyl-D-glucose resulted in an immediate halt of protein degradation and spore swelling. These results suggest that protein is a major endogenous reserve in $M$. racemosus sporangiospores and that its turnover is a necessary event for glucose-triggered germination.
\end{abstract}

\section{INTRODUCTION}

Sporangiospores of Mucor racemosus treated with a germinant undergo a morphological transition from an elliptical spore of $20 \mu \mathrm{m}^{3}$ to a spherical cell of $130 \mu \mathrm{m}^{3}$ with subsequent germ tube formation (Tripp \& Paznokas, 1981). Analysis of the germination synchrony led to the observation that two physiologically distinct spore types exist. Sporangiospores produced on a nutritionally complex medium, denoted C-spores, are induced to germinate by a wide variety of compounds including glucose, cellobiose, xylose or glutamate. They are also triggered to initiate germination and increase in volume to about $90 \mu^{3}$ by several non-metabolizable glucose analogues such as 3-O-methyl-D-glucose (3-OMDG) (Tripp \& Paznokas, 1982). The initiation signal was shown to be required continuously since the removal of 3-OMDG resulted in an immediate halt in swelling; re-addition of 3-OMDG restored swelling. Sporangiospores produced on a defined minimal medium, denoted $\mathbf{M}$-spores, are triggered by only a few specific compounds structurally resembling glucose, or by nutritionally complex mixtures such as peptone. Non-metabolizable glucose analogues also trigger $\mathrm{M}$-spores, but only in the presence of an exogenous carbon source such as glutamate. M-spores can be made competent to germinate on glutamate if they are pretreated with glucose for $90 \mathrm{~min}$. Protein synthesis was necessary for the development of competence.

In the present study, we have investigated the relationship between sporangiospore germination ability and the intracellular content of various components such as amino acids,

† Present address: Department of Biology, University of California-San Diego, San Diego, California, U.S.A. 
organic carbon and protein. Uptake and incorporation of glutamate and leucine during germination was also examined. It is suggested that glucose may trigger germination by signalling the breakdown of endogenous protein reserves. The subsequent increase of free amino acids may be the dormancy-breaking step.

\section{METHODS}

Organism and culture conditions. Mucor racemosus (M. lusitanicus) ATCC 1216B was used in all experiments. The asexual sporangiospores designated $\mathrm{C}$ - and $\mathrm{M}$-spores were produced on two types of media as described previously (Tripp \& Paznokas, 1981, 1982). Sporangiospores were harvested $5 \mathrm{~d}$ after inoculation, washed twice in distilled water and counted with either a haemocytometer or a Coulter counter, and used as the inoculum.

Germination test media. The minimal germination medium (MGM) was a modification of the MSM in which L-glutamate and agar were omitted and D-glucose was replaced by other substrates at the various concentrations noted. Portions $(10 \mathrm{ml})$ of MGM contained in $50 \mathrm{ml}$ flasks were inoculated to a final concentration of $1 \times 10^{6}$ sporangiospores $\mathrm{ml}^{-1}$ and incubated at $25^{\circ} \mathrm{C}$ in a gyrorotatory water bath incubator shaking at $150 \mathrm{rev} \cdot \mathrm{min}^{-1}$.

Initiation of spore germination. Dormant $M$. racemosus sporangiospores average $20 \mu \mathrm{m}^{3}$. Upon treatment with a suitable germinant, an increase in volume can be observed with a Coulter counter (model ZB1) and Channelyzer (model II) as described previously (Tripp \& Paznokas, 1981). For these studies, spores that had increased to a volume $>\mathbf{4 5} \mu \mathrm{m}^{3}$ were considered to have initiated germination.

Uptake and incorporation of $\mathrm{L}$-glutamate and $\mathrm{L}$-leucine. The uptake of $\mathrm{L}$-glutamate and $\mathrm{L}$-leucine by $\mathrm{M}$ - and $\mathrm{C}$-spores incubated under permissive or non-permissive germination conditions was measured by following the accumulation of $\mathrm{L}-\left[\mathrm{U}-{ }^{14} \mathrm{C}\right.$ glutamate $\left(1 \mathrm{mM} ; 1 \mu \mathrm{Ci}_{\mu} \mathrm{mol}^{-1}, 37 \mathrm{kBq} \mu \mathrm{mol}^{-1}\right)$ or $\mathrm{L}-\left[\mathrm{U}-{ }^{14} \mathrm{C}\right]$ leucine $(0.5 \mathrm{mM} ; 1 \mu \mathrm{Ci}$ $\left.\mu \mathrm{mol}^{-1}, 37 \mathrm{kBq} \mu \mathrm{mol}^{-1}\right)$. Spores $\left(5 \times 10^{6} \mathrm{ml}^{-1}\right)$ in MGM (pH 5.0 except where noted) containing the ${ }^{14} \mathrm{C}$-labelled amino acid and the appropriate addition (glucose, 3-OMDG, L-glutamate or none as noted) were incubated in a gyrorotatory water bath shaker at $25^{\circ} \mathrm{C}$. Samples $(0.5 \mathrm{ml})$ were collected by vacuum filtration on a Millipore membrane filter $(0.45 \mu \mathrm{m}, \mathrm{HAWP})$ and washed with $10 \mathrm{ml}$ of ice-cold unlabelled medium. The filters were counted as described previously (Tripp \& Paznokas, 1982), and the results are reported as nmol accumulated per $10^{6}$ spores. The incorporation of L-glutamate or L-leucine was measured by incubating the spores as described above, and then subjecting samples $(1.0 \mathrm{ml})$ to a $30 \mathrm{~min}$ trichloroacetic acid treatment $(5 \%, \mathrm{w} / \mathrm{v}$, final concentration) at $4{ }^{\circ} \mathrm{C}$. The samples were collected by vacuum filtration and washed with $10 \mathrm{ml}$ of $5 \%$ trichloroacetic acid and $4 \mathrm{ml}$ of $70 \%$ ethanol, both at $4{ }^{\circ} \mathrm{C}$. The filters were counted as described above and the results are presented as nmol incorporated per $10^{6}$ spores.

Determination of free amino acid pools in dormant spores. Three separate preparations of C- and $\mathrm{M}$-spores were harvested, washed twice with water and counted with a Coulter counter. Each spore preparation was then suspended in $4 \mathrm{ml}$ of $0.1 \mathrm{M}-\mathrm{HCl}\left(5 \times 10^{8}\right.$ spores $\left.\mathrm{ml}^{-1}\right)$ and subjected to five cycles of freezing and thawing using liquid nitrogen. The suspensions were pelleted $\left(10000 \mathrm{~g}, 30 \mathrm{~min}, 4^{\circ} \mathrm{C}\right)$ and the top $2 \mathrm{ml}$ of the supernatants were taken and lyophilized. The samples were resuspended in $750 \mu \mathrm{l}$ of buffer and an amino acid analysis (Beckman amino acid analyser, model 121) was performed on a portion of each sample. The results are presented as nmol amino acid per $10^{9}$ spores.

Endogenous carbon loss during germination. Total organic carbon in spores incubated under germinating and non-germinating conditions was measured. Samples $(10 \mathrm{ml})$ of spores $\left(5 \times 10^{6} \mathrm{ml}^{-1}\right)$ incubated in MGM/ 3-OMDG $(20 \mathrm{~mm})$ were collected by centrifugation $\left(4000 \mathrm{~g}, 4^{\circ} \mathrm{C}\right)$ and the pellets were washed once with glass-distilled water. The pellets were resuspended in glass-distilled water and the spore titre was determined with a Coulter counter. Carbon was determined using a total organic carbon analyser (Beckman model 915B) as described by the manufacturer. The results are presented as $\mu \mathrm{g}$ organic carbon per $10^{6}$ spores.

Determination of sporangiospore protein. Samples $(10 \mathrm{ml})$ of spores $\left(5 \times 10^{6} \mathrm{ml}^{-1}\right)$ incubated as noted in Table 3 legend were collected by centrifugation and washed once with glass-distilled water. The pellets were resuspended in glass-distilled water and counted with a Coulter counter. $\mathrm{NaOH}$ (final concentration $1 \mathrm{M}$ ) was added to the spore suspensions and heated to $100^{\circ} \mathrm{C}$ for $20 \mathrm{~min}$. Protein determinations were performed by the Lowry method.

Chemicals. ${ }^{14} \mathrm{C}$-labelled L-glutamate and L-leucine were purchased from New England Nuclear. The glucose analogue 3-O-methyl-D-glucose (3-OMDG) was used at $20 \mathrm{mM}$ and was purchased from Aldrich Chemical Co. Cyclic AMP was used at $10 \mathrm{~mm}$ and amino acids were usually $100 \mathrm{~mm}$ except where noted. These and all other chemicals were reagent grade and purchased from Sigma.

\section{RESULTS}

\section{Germination induced by amino acids}

A number of amino acids and combinations of amino acids were tested for their ability to induce germination of Mucor racemosus sporangiospores produced on either a minimal 
Table 1. Germination of $M$. racemosus sporangiospores induced by L-amino acids and L-amino acid combinations

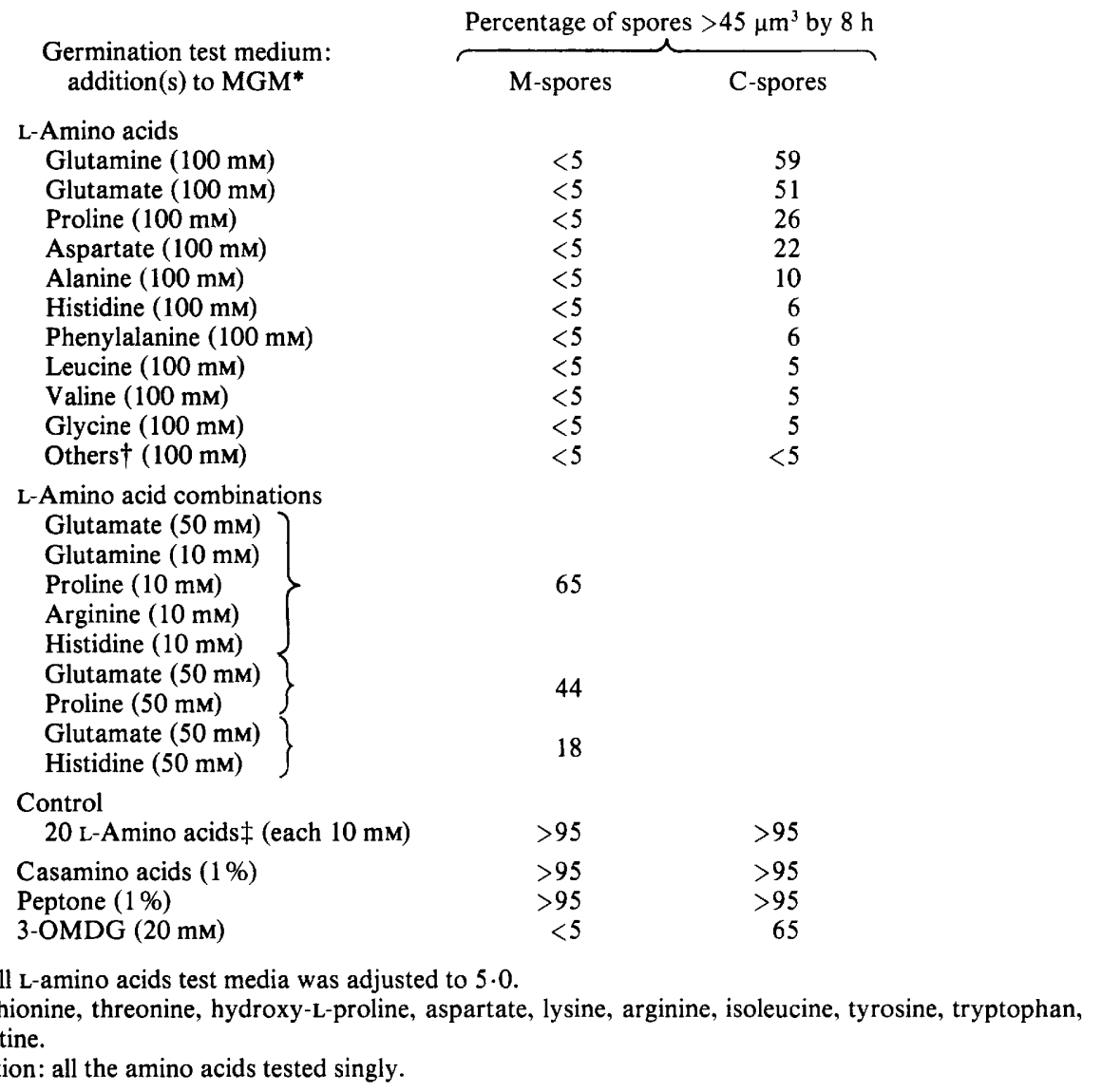

(M-spores) or a complex (C-spores) sporulation medium. No single amino acid induced $\mathrm{M}$-spore germination. Variable percentages of $\mathrm{C}$-spores were induced to germinate by some, but not all of the amino acids (Table 1). A mixture of $20 \mathrm{~L}$-amino acids induced greater than $95 \%$ of both $\mathrm{M}$ - and $\mathrm{C}$-spores to germinate (Table 1). Amino acid mixtures representing the six major groups [in terms of where their carbon skeletons enter the tricarboxylic acid (TCA) cycle, i.e. at $\alpha$-ketoglutarate, succinyl-CoA, fumarate, oxaloacetate, acetoacetyl-CoA or acetyl-CoA] were added to MGM/glutamate medium and tested for their ability to induce M-spore germination. The mixture of amino acids which enter the TCA cycle through $\alpha$-ketoglutarate (Glu, Gln, Pro, Arg, His) induced a high level of M-spore germination. The tandem mixtures of glutamate and proline or glutamate and hydroxy-L-proline were almost as effective (Table 1). Other tandem mixtures among this group (Glu, Gln, and Glu, Arg) as well as mixtures among the other five groups [Ile, Val, Met (14\%); Phe, Tyr (11\%); Asp, Asn $(<5 \%)$; Leu, Lys, Trp (11\%); Ala, Thr, Gly, Ser, Cysteine $(<5 \%)$ ] were not effective inducers of $\mathrm{M}$-spore germination.

\section{Free amino acid pools in sporangiospores}

Since peptone, Casamino acids and certain amino acid combinations supported M-spore germination, where single amino acids did not (Table 1), the free amino acid pools in $\mathrm{M}$ - and $\mathrm{C}$-spores were analysed to determine if qualitative or quantitative differences existed. Both $\mathrm{C}$ - 


\section{Table 2. Free amino acid pools in $M$. racemosus sporangiospores}

Results are the average values \pm standard deviation for three separate sporangiospore preparations.

\begin{tabular}{|c|c|c|c|}
\hline \multirow{2}{*}{ Compound } & \multicolumn{2}{|c|}{ Concentration (nmol per $10^{9}$ spores) } & \multirow{2}{*}{$\begin{array}{l}\text { Concentration ratio } \\
\text { (C-spores/M-spores) }\end{array}$} \\
\hline & C-spores & M-spores & \\
\hline Glutamate & $627 \pm 54 \cdot 1$ & $686 \pm 126 \cdot 5$ & \\
\hline Glutamine & $1188 \pm 251 \cdot 7$ & $1077 \pm 510.0$ & \\
\hline Arginine & $165 \pm 9.0$ & $212 \pm 81.7$ & \\
\hline Histidine* & $272 \pm 14.8$ & $119 \pm 8.8$ & $2 \cdot 3$ \\
\hline Proline & $291 \pm 45.8$ & $241 \pm 99.7$ & \\
\hline Hydroxy-L-proline* & $1608 \pm 325.4$ & $11 \pm 12.1$ & 138 \\
\hline Isoleucine & $21 \pm 1.4$ & $29 \pm 6.4$ & \\
\hline Valine & $100 \pm 15 \cdot 1$ & $112 \pm 14 \cdot 1$ & \\
\hline Methionine* & $22 \pm 6.3$ & $2 \pm \quad 0.39$ & $7 \cdot 8$ \\
\hline Phenylalanine & $19 \pm$ & $16 \pm$ & \\
\hline Tyrosine* & $29 \pm 7.4$ & $14 \pm \quad 2.3$ & $2 \cdot 1$ \\
\hline Aspartate & $135 \pm 27.8$ & $174 \pm 23.6$ & \\
\hline Asparagine* & $810 \pm 184.8$ & $463 \pm 109 \cdot 8$ & 1.8 \\
\hline Leucine & $20 \pm 4.7$ & $24 \pm 6.0$ & \\
\hline Lysine & $84 \pm 14 \cdot 0$ & $76 \pm$ & \\
\hline Alanine & $436 \pm 47.8$ & $388 \pm 32.4$ & \\
\hline Threonine* & $95 \pm 21.8$ & $49 \pm 9.1$ & 1.9 \\
\hline Glycine & $132 \pm 8.9$ & $154 \pm 5.5$ & \\
\hline Serine* & $245 \pm 20 \cdot 3$ & $129 \pm 24.9$ & 1.9 \\
\hline Cysteine & $30 \pm 3.8$ & $32 \pm 6 \cdot 1$ & \\
\hline Ornithine & $24 \pm$ & $18 \pm$ & \\
\hline$\alpha$-Aminoadipic acid* & $34 \pm \quad 5.4$ & $17 \pm$ & $2 \cdot 0$ \\
\hline$\gamma$-Aminobutyric acid & $87 \pm 40.2$ & $26 \pm 21.0$ & \\
\hline Cystathione & $3 \pm \quad 1.6$ & $5 \pm 1 \cdot 3$ & \\
\hline Phosphoserine* & $8 \pm 5.8$ & $20 \pm \quad 2.4$ & 0.43 \\
\hline Phosphoethanolamine* & Not detected & $293 \pm 81 \cdot 4$ & \\
\hline $\mathrm{NH}_{3}^{*}$ & $608 \pm 114 \cdot 3$ & $180 \pm 30 \cdot 0$ & $3 \cdot 4$ \\
\hline
\end{tabular}

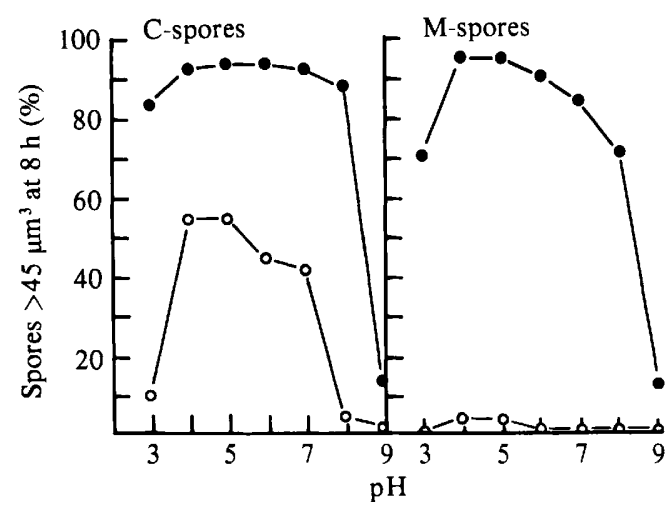

Fig. 1. Effect of $\mathrm{pH}$ on $\mathrm{C}$-spore and $\mathrm{M}$-spore germination ability in MGM/glutamate (O) or MGM/glutamate plus $20 \mathrm{mM}-3-\mathrm{OMDG}(\mathbf{O})$.

and $\mathrm{M}$-spores contained all 20 amino acids but $\mathrm{C}$-spores had significantly higher amounts of methionine, histidine, tyrosine, asparagine, threonine, serine and hydroxy-L-proline (Table 2), particularly hydroxy-L-proline (138-fold higher) and methionine (7-8-fold higher). Several other amino compounds were detected and C-spores contained significantly more $\alpha$-aminoadipic acid and $\mathrm{NH}_{3}$. $\mathrm{M}$-spores, however, contained more phosphoserine $(2 \cdot 3$-fold 


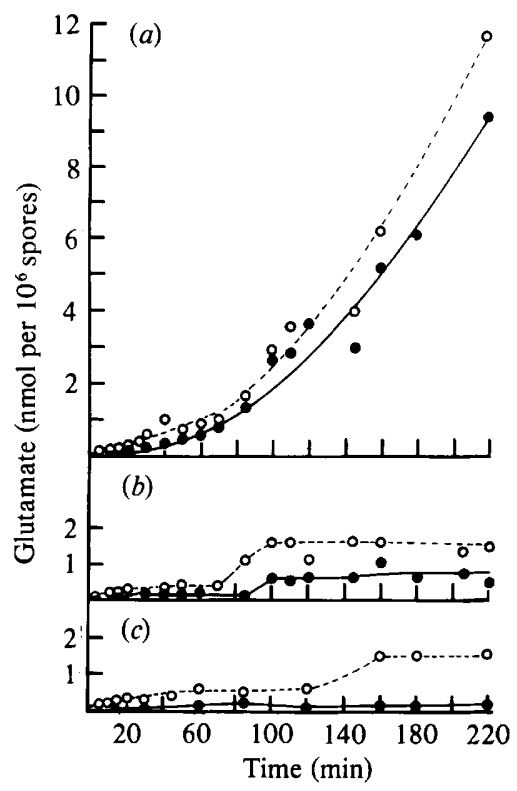

Fig. 2. Effect of 3-OMDG and cycloheximide on the accumulation (O----O) and incorporation (-) of glutamate at pH 3.0 by C-spores: (a) MGM plus 20 mM-3-OMDG, pH 3.0 (permissive germination conditions); (b) MGM, pH 3.0 (non-permissive); (c) MGM plus $20 \mathrm{mM}-3-\mathrm{OMDG}$ and $300 \mathrm{~g}$ cycloheximide $\mathrm{ml}^{-1}$, $\mathrm{pH} 5 \cdot 0$ (non-permissive).

higher). Phosphoethanolamine was found in M-spores but was not detected in C-spores (Table 2).

\section{Effect of $p H$ on spore germination}

Greater than $95 \%$ of $\mathrm{M}$ - and $\mathrm{C}$ - spores germinated at similar rates in $\mathrm{MGM} /$ glucose (100 mM) or MGM/peptone (1\%) throughout the $\mathrm{pH}$ range 3-9. M-spores did not germinate in $\mathrm{MGM} /$ glutamate at any $\mathrm{pH}(3-9)$ unless 3-OMDG was also added to the medium (Fig. 1). $\mathrm{C}$-spores did not germinate in MGM/glutamate at $\mathrm{pH} \mathrm{3,8}$ or 9. The addition of 3-OMDG restored a high level of germination (Fig. 1) except at pH 9.

\section{Uptake of glutamate}

While $\mathrm{M}$-spores were unable to initiate germination in $\mathrm{MGM} / \mathrm{glutamate}$ at any $\mathrm{pH}$, a percentage $(50-75 \%)$ of $\mathrm{C}$-spores could germinate on glutamate at $\mathrm{pH} 5 \cdot 0$, but not $\mathrm{pH} 3.0$. The addition of glucose or 3-OMDG restored germination to $>80 \%$ for all of the above conditions (Tripp \& Paznokas, 1981). One explanation is that these non-permissive germination conditions reflect the inability of the spores to take up glutamate. If so, one should find different uptake kinetics for permissive and non-permissive conditions. No significant difference was observed in the kinetics of glutamate uptake under any of the following permissive or non-permissive conditions: for M-spores - MGM, MGM/3-OMDG, MGM (pH 3.0), MGM/3-OMDG ( $\mathrm{pH} 3.0$ ) were non-permissive conditions and MGM/ glucose was a permissive condition; for C-spores - MGM and MGM (pH 3.0) were non-permissive conditions and MGM/glucose, MGM/3-OMDG, MGM/3-OMDG (pH 3.0) were permissive conditions.

\section{Accumulation and incorporation of glutamate and leucine}

Although the initial rates of glutamate uptake were the same for both germinating and non-germinating spores, the amounts of glutamate (Fig. 2) and leucine (Fig. 3) accumulated 


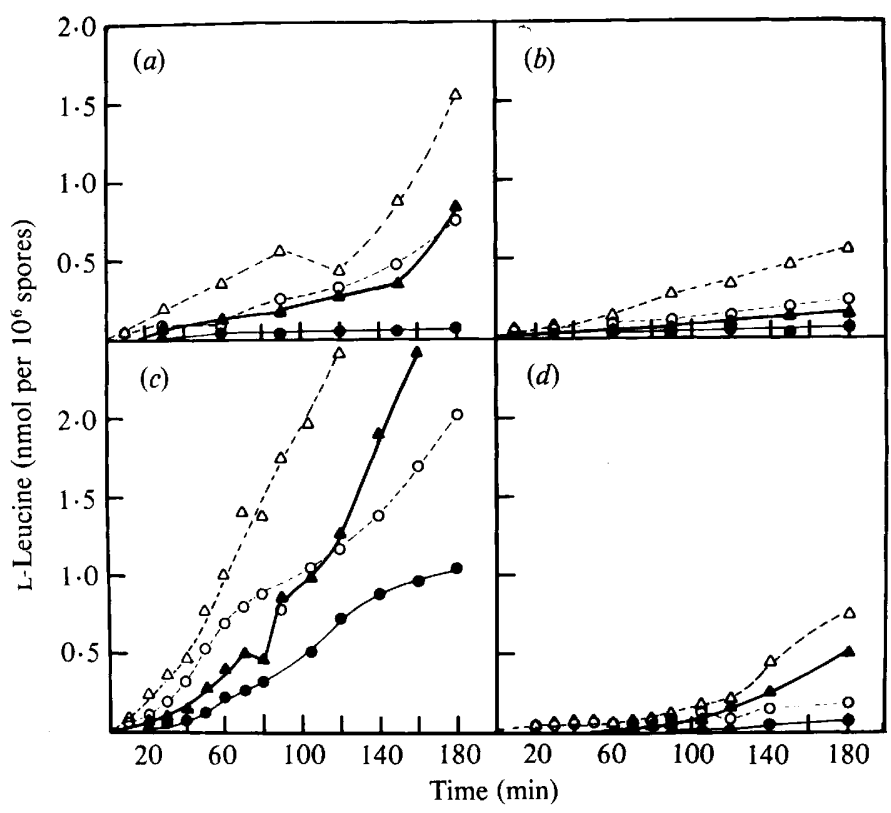

Fig. 3. Effect of various permissive and non-permissive germination conditions on the accumulation $(--)$ and incorporation (- - of leucine by C-spores: (a) C-spores in MGM (O, ; non-permissive) and MGM plus $20 \mathrm{mM}-3-\mathrm{OMDG}(\triangle, \Delta$; permissive); (b) $\mathrm{M}$-spores in MGM (O, $\bigcirc$; nor-permissive) and MGM plus $20 \mathrm{mM}-3-O M D G(\triangle, \Delta$; non-permissive); (c) C-spores in MGM/glutamate (100 mM) $(O, O$; permissive) and MGM/glutamate plus $20 \mathrm{mM}$-3-OMDG $(\Delta, \mathbf{\Delta}$; permissive); (d) $\mathrm{M}$-spores in MGM/glutamate (100 mM) (O, ; non-permissive) and MGM/glutamate plus $20 \mathrm{mM}$-3-OMDG $(\triangle, \Delta$; permissive).

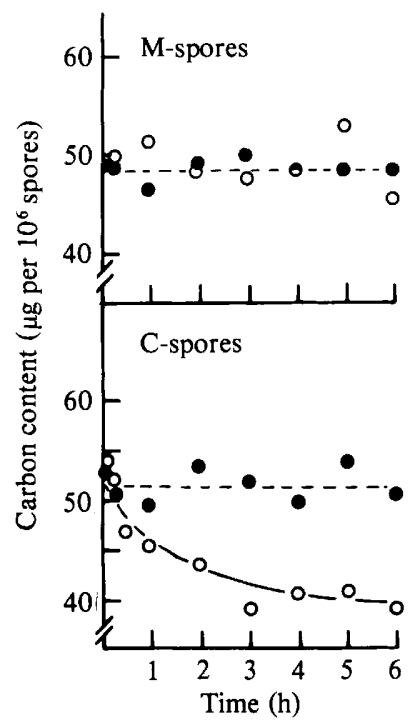

Fig. 4. Effect of 3-OMDG on total organic carbon content of M-spores and C-spores. Spores were incubated in MGM (O) or MGM plus $20 \mathrm{mM}-3-\mathrm{OMDG}(\mathrm{O})$. Carbon was determined as described in Methods.

and incorporated were much greater under permissive germination conditions than non-permissive conditions. Incorporation but not accumulation was completely inhibited by cycloheximide (Fig. 2c). 
Table 3. Relationship between 3-O-methyl-D-glucose-triggered germination and total spore protein

\begin{abstract}
Spores were either (1) harvested and washed as described in Methods and stored frozen until needed for the protein determination, or (2) aerated by shaking at $25^{\circ} \mathrm{C}$ in MGM for $5 \mathrm{~h}$, harvested by centrifugation, washed twice in water and stored frozen, or (3) treated as in (2) except 20 mM-3-OMDG was added to the MGM. Results show the average value \pm standard deviation for four replicates.
\end{abstract}

\begin{tabular}{lcc} 
Treatment & \multicolumn{2}{c}{ Total protein ( $\mu$ g per $10^{6}$ spores) } \\
\cline { 2 - 3 } 1. None & $10.5 \pm 0.83$ & $6.8 \pm 0.04$ \\
2. MGM & $12.1 \pm 1.9$ & $7.1 \pm 0.48$ \\
3. 3-OMDG & $5.6 \pm 0.41$ & $6.7 \pm 0.36$
\end{tabular}

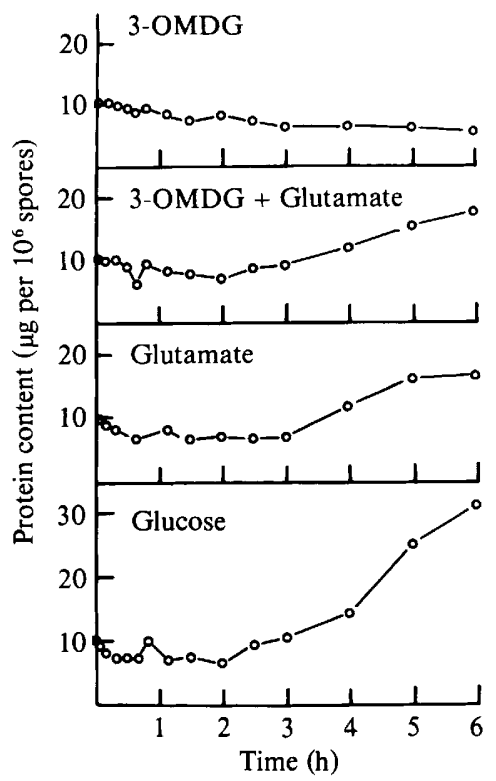

Fig. 5

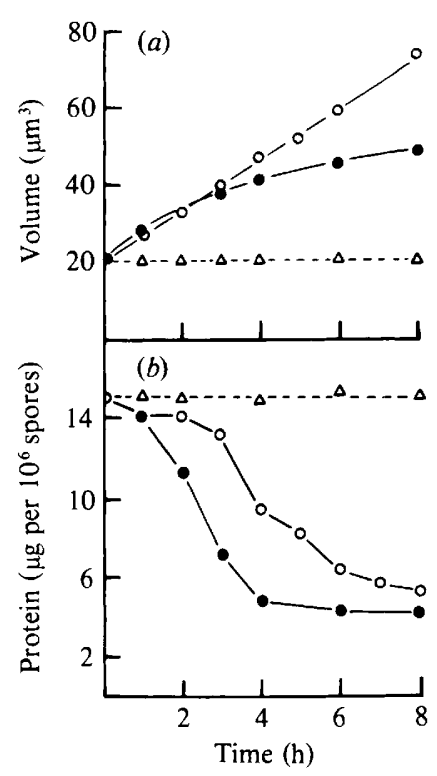

Fig. 6

Fig. 5. Changes in protein content during germination of $\mathrm{C}$-spores incubated under a variety of conditions: MGM plus $20 \mathrm{~mm}-3-O M D G ;$ MGM plus $20 \mathrm{~mm}-3-O M D G$ and $100 \mathrm{~mm}$-glutamate; MGM plus $100 \mathrm{mM}$-glutamate; or MGM plus $100 \mathrm{mM}$-glucose.

Fig. 6. Stimulatory effect of cyclic AMP on protein loss in C-spores initiated by 3-OMDG: spore swelling (a) and protein (b) in MGM plus $10 \mathrm{mM}$-cyclic AMP $(\triangle)$; MGM plus $20 \mathrm{mM}-3-\mathrm{OMDG}(\mathrm{O})$; or MGM plus 10 mM-cyclic AMP and 20 mM-3-OMDG (O).

\title{
Effect of 3-O-methyl-D-glucose on total sporangiospore carbon
}

C-spores treated with 3-OMDG, a glucose analogue which is not metabolized by $M$. racemosus spores (Tripp \& Paznokas, 1982), initiate germination and increase in volume to $70-90 \mu^{3}$. Germ tubes do not appear until the cells achieve a volume of approximately $130 \mu \mathrm{m}^{3}$. One explanation is that only $\mathrm{C}$-spores contain endogenous reserves which are metabolized in response to the germination signal (i.e. 3-OMDG). Total organic carbon analysis of $\mathrm{M}$ - and $\mathrm{C}$-spores supports this notion (Fig. 4). C-spores treated with 3-OMDG showed a decrease in carbon in an apparent inverse relationship to increases in spore volume. Both carbon loss and swelling ceased by $6-8 \mathrm{~h}$ and no further changes were observed even after $24 \mathrm{~h}$ incubation. Treatment of $\mathrm{M}$-spores with 3-OMDG did not influence the total carbon content (Fig. 4) during $24 \mathrm{~h}$. 


\section{Relationship between 3-O-methyl-D-glucose-triggered germination and total spore protein}

Total protein was determined for $\mathrm{C}$ - and $\mathrm{M}$-spore preparations before and after treatment with 3-OMDG. Freshly harvested $\mathrm{C}$-spores contained nearly twice as much protein as $\mathrm{M}$-spores (Table 3). C-spores triggered by 3-OMDG increased in volume to about $65 \mu \mathrm{m}^{3}$ by $5 \mathrm{~h}$ but decreased in total protein by about one-half (Table 3). $\mathrm{M}$-spore protein was not quantitatively affected by $3-O M D G$ even after $24 \mathrm{~h}$ incubation.

\section{Protein content of germinating spores}

Protein synthesis is required for germination in most, if not all, fungal spore systems. This also appears to be the case for $M$. racemosus since cycloheximide completely blocks germination under permissive incubation conditions (Tripp \& Paznokas, 1982; Orlowski \& Sypherd, 1978). However, C-spores incubated under a variety of permissive conditions showed a decrease in total protein (Fig. 5). Treatment of $\mathrm{C}$-spores with 3-OMDG (no carbon source) resulted in a sustained protein loss which was proportional to the degree of swelling; removal of 3-OMDG resulted in an immediate cessation of both protein loss and swelling. Treatment of C-spores with 3-OMDG + cyclic AMP stimulated the rate of protein loss. Also, the degree of $\mathrm{C}$-spore development after $20 \mathrm{~h}$ incubation in 3-OMDG + cyclic AMP was significantly less $\left(48 \mu \mathrm{m}^{3}\right)$ than in the same C-spores incubated in 3-OMDG alone $\left(88 \mu \mathrm{m}^{3}\right)$ (Fig. 6). Treatment of $\mathrm{M}$-spores with $3-\mathrm{OMDG}$ did not affect their total protein content (Table 3).

\section{DISCUSSION}

As previously reported (Tripp \& Paznokas, 1981), greater than $95 \%$ of $\mathrm{M}$ - and C-spores of $M$. racemosus germinate in MGM containing glucose, peptone or Casamino acids; but no $\mathrm{M}$-spores and only a portion of $\mathrm{C}$-spores germinate in the presence of glutamate or alanine. One explanation is that only certain amino acids can signal germination of $M$. racemosus M-spores as do only certain carbohydrates (Tripp \& Paznokas, 1982). Germination of Bacillus megaterium spores, for example, is triggered by glucose and certain glucose analogues and also by proline and proline analogues but not by various other carbohydrates or amino acids (Rossignol \& Vary, 1979; Vary, 1978). No single amino acid induced $M$. racemosus $\mathrm{M}$-spore germination and only glutamate and glutamine induced $50 \%$ or more of C-spores to germinate (Table 1). A specific combination of amino acids present in peptone may be acting in concert as a germination signal analogous to glucose. To test this hypothesis several amino acid mixtures were used. Only combinations of amino acids which enter the TCA cycle through $\alpha$-ketoglutarate induced significant $\mathbf{M}$-spore germination. The combinations of glutamate and proline, or glutamate and hydroxy-L-proline were particularly effective.

The ability of certain amino acid combinations to trigger $\mathrm{M}$-spore germination prompted us to examine the free amino acid pools in $\mathbf{M}$ - and $\mathrm{C}$-spores since one or more of the amino acids of the $\alpha$-ketoglutarate family may have been absent or low in $\mathbf{M}$-spores. Similar amounts were found for most amino acids in both $\mathbf{M}$ - and C-spores (Table 2). Two qualitative exceptions were noted. First, extremely high amounts of hydroxy-L-proline existed in $\mathrm{C}$-spores, but it was barely detectable in M-spores. Secondly, a high amount of phosphoethanolamine was present in $\mathrm{M}$-spores, but was not detected in $\mathrm{C}$-spores. The biological significance of these findings is unknown. Very high amounts of proline relative to the other amino acids accumulate in sporulating cells of Saccharomyces cerevisiae, $S$. oleaceus and $S$. mellis (Ramirez \& Miller, 1964). These authors suggested that proline may not be metabolized during sporulation but preferentially used as an endogenous reserve during germination, or may play a role in the maintenance of dormancy. Hydroxy-L-proline and phosphoethanolamine may perform one or more of these roles in $M$. racemosus, or alternatively their presence may simply be a result of the different $\mathrm{M}$ - and $\mathrm{C}$-sporulation conditions. 
Since all 20 amino acids are found in $M$. racemosus spores, amino acids should not be limiting protein synthesis. Therefore, we examined protein synthesis in dormant and germinating spores. Only germinating spores incorporated significant amounts of glutamate or leucine into trichloroacetic acid precipitable material (Figs 2 and 3). Cycloheximide completely blocked this incorporation. These results demonstrate that dormant spores are not synthesizing protein even though substantial amino acid pools exist (Table 2). These amino acids could, however, be sequestered in some type of storage vesicle.

3-OMDG triggers $\mathrm{C}$-spores to initiate germination and increase in volume by four- to five-fold (Tripp \& Paznokas, 1981). Protein synthesis is required for this volume increase. Under these conditions spore development is sustained solely by endogenous reserves. Utilization of fungal spore endogenous reserves during the initial stages of germination is not unique to $M$. racemosus, for example, dry mass and specific gravity of the microconidia of Trichophyton mentagrophytes decrease significantly during germination (Hashimoto et al., 1972). Since exogenously supplied amino acids induce $M$. racemosus spore germination, it is difficult to understand how the spore could maintain dormancy and contain free amino acid pools at the level that would be required to function as an endogenous reserve. On the other hand, it would be to the advantage of the spore to maintain a preformed supply of amino acids.

The ability of protein to function as an endogenous amino acid reserve has been demonstrated in several fungal systems including Aspergillus (Zonneveld, 1980), Blastocladiella (Lodi \& Sonneborn, 1974), Dictyostelium (Cleland \& Coe, 1969) and Podospora (Begueret \& Bernet, 1973). Hence, we speculated that the endogenous reserve in Mucor racemosus spores might be protein. This notion was supported by the following observations. First, freshly harvested $\mathrm{C}$-spores contained about twice as much protein as $\mathrm{M}$-spores. Secondly, triggering of C-spores with 3-OMDG resulted in a sustained protein loss of about $50 \%$, to the level of freshly harvested $\mathrm{M}$-spores (Table 3). Thirdly, M-spore total protein was not affected by 3-OMDG treatment. Interestingly, the addition of exogenous cyclic AMP stimulated the rate of 3-OMDG-triggered protein loss in C-spores but did not initiate it (Fig. 6), and may explain why the rate of swelling but not the percentage of a C-spore population germinating on glutamate was stimulated by cyclic AMP (Wertman \& Paznokas, 1981; Tripp \& Paznokas, 1981). The observation that cyclic AMP stimulates the rate of protein degradation is not unique to $M$. racemosus spore germination. Increasing cyclic AMP concentrations correspond to increasing protease activity during the differentiation of Aspergillus nidulans under conditions where endogenous protein reserves supply the carbon and energy source (Zonneveld, 1980). Fourthly, removal of 3-OMDG resulted in an immediate cessation of both protein loss and spore swelling. The necessity for the continuous presence of 3-OMDG (Tripp \& Paznokas, 1982) supports the hypothesis that it acts as a positive effector molecule. Conceivably, 3-OMDG may interact directly with a protease or act indirectly through a regulatory protein. An initial protein loss was also observed in C-spores germinating on glutamate, demonstrating that it is not unique to 3-OMDG-triggered germination (Fig. 5).

It appears that $\mathrm{pH}$ can influence the germination of $M$. racemosus sporangiospores. $\mathrm{C}$-spores did not germinate on glutamate at $\mathrm{pH} 3$ or 8 except when 3-OMDG, glucose or peptone was present (Fig. 1). This would suggest that there might be a pH-dependent conversion of glutamate to an initiation signal molecule(s). M-spores did not germinate on glutamate regardless of $\mathrm{pH}$ except in the presence of 3-OMDG, glucose or peptone. These data suggest that two germination trigger mechanisms exist in $M$. racemosus spores: (I) a $\mathrm{pH}$-independent pathway present in both $\mathrm{M}$ - and $\mathrm{C}$-spores and (II) a $\mathrm{pH}$-dependent pathway apparently existing only in $\mathrm{C}$-spores. One explanation for these observations is that compounds other than glucose may be excluded from spores depending on $\mathrm{pH}$ and spore type and that glucose may trigger uptake of these compounds. In disagreement with this hypothesis, the initial rates of glutamate uptake for $\mathrm{M}$ - and $\mathrm{C}$-spores placed into permissive 
PH-INDEPENDENT PATHWAY

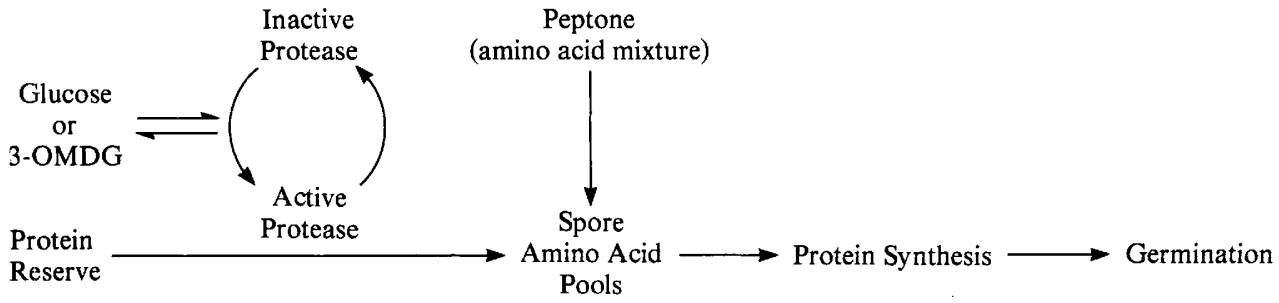

pH-DEPENDENT PATHWAY

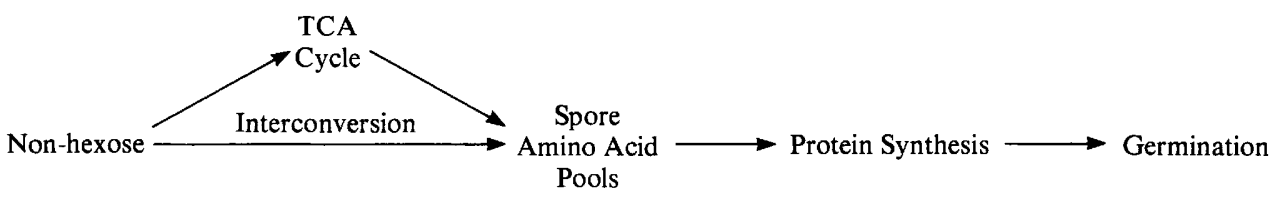

Fig. 7. Hypothetical mechanism by which Mucor racemosus sporangiospores initiate germination.

(glucose or 3-OMDG) or non-permissive (MGM or glutamate, $\mathrm{pH} 3$ ) germination conditions were the same (data not shown). Similar results were obtained with leucine (Fig. 3) and lysine (data not shown).

Alternatively, glucose may 'turn on' macromolecular synthesis either by direct interaction with a regulatory protein, or indirectly by signalling the mobilization of endogenous reserves, resulting in an intracellular flood of biosynthetic intermediates. According to this hypothesis M-spores would lack the endogenous reserves necessary for energy production or biosynthesis. As mentioned above, M-spores contained about one-half the protein of $\mathrm{C}$-spores. This could explain why $\mathrm{M}$-spores were not triggered by the non-metabolizable glucose analogue 3-OMDG unless a carbon source was present.

From the information presented here, we propose the following model for the regulation of dormancy in $M$. racemosus sporangiospores (Fig. 7). For the $\mathrm{pH}$-independent pathway, we propose that the glucose molecule interacts indirectly with a regulatory protein or directly with a protease to activate it. The activated protease degrades the endogenous protein reserve supplying a flood of amino acids which are metabolized as an energy source or utilized for macromolecular synthesis. Further, we propose that it is this sudden increase in free amino acids which triggers protein synthesis and is responsible for the synchronous germination on glucose and 3-OMDG. Supplying a mixture of amino acids exogenously (e.g. peptone) circumvents the requirement for glucose. This may explain why Orlowski \& Sypherd (1978) did not see a net protein loss in $M$. racemosus spores germinating on a yeast extract, peptone and glucose medium.

Evidence for the $\mathrm{pH}$-dependent pathway only exists for $\mathrm{C}$-spores. We propose that this is the pathway by which triggering occurs by non-hexoses. The non-hexose must be metabolized (e.g. via the TCA cycle) to supply the carbon skeletons for amino acid interconversion. When the free amino acid pools reach a critical concentration, germination is initiated. It is probable that the conversion of the non-hexose to one or more specific amino acids is the $\mathrm{pH}$-dependent step. An alternative would be that non-hexoses would have to be converted to glucose which then would initiate germination.

The mechanism by which a compound triggers germination in a dormant spore is unknown. Numerous models have been proposed (Dring \& Gould, 1975; Prasad et al., 1972; Vary, 1978; Woese et al., 1968). Our studies suggest that the control over dormancy in $M$. racemosus sporangiospores is at the level of protein metabolism - both degradation and 
synthesis. Compounds which trigger protein degradation (3-OMDG) or protein synthesis (amino acids) result in the breaking of the dormant state.

This work was supported in part by PHS grant no. GM24670. We wish to thank M. Kahn, H. Nakata and M.

Pall for many helpful discussions and review of this manuscript.

\section{REFERENCES}

Begueret, J. \& Bernet, J. (1973). Proteolytic enzymes and protoplasmic incompatibility in the fungus Podospora anserina. Nature, London 243, 94-96.

Cleland, S. \& Coe, E. (1969). Conversion of aspartic acid to glucose during culmination of Dictyostelium discoideum. Biochimica et biophysica acta 192, 446-452.

DrING, G. J. \& Gould, G. W. (1975). Electron transport-linked metabolism during germination of Bacillus cereus spores. In Spores VI, pp. 488-494. Edited by P. Gerhardt, R. N. Costilow \& H. L. Sadoff. Washington, D.C.: American Society for Microbiology.

Hashimoto, T., Wu, C. D. R. \& Blumenthal, H. J. (1972). Characterization of L-leucine-induced germination of Trichophyton mentagrophytes microconidia. Journal of Bacteriology 112, 967976.

Lodi, W. R. \& Sonneborn, D. R. (1974). Protein degradation and protease activity during the life cycle of Blastocladiella emersonii. Journal of Bacteriology 117, 1035-1042.

ORLOWSKI, M. \& SYPHERD, P. S. (1978). Regulation of macromolecular synthesis during hyphal germ tube emergence from Mucor racemosus sporangiospores. Journal of Bacteriology 134, 76-83.

Prasad, C., Diesterhaft, D. \& Freese, E. (1972). Initiation of spore germination in glycolytic mutants of Bacillus subtilis. Journal of Bacteriology 110, 321-328.

RAmirez, C. \& Miller, J. J. (1964). The metabolism of yeast sporulation. VI. Changes in amino acid content during sporogenesis. Canadian Journal of Microbiology 10, 623-631.

Rossignol, D. P. \& VARY, J. C. (1979). Biochemistry of L-proline triggered germination of Bacillus megaterium spores. Journal of Bacteriology 138, 431441.

TrIPp, M. L. \& Paznokas, J. L. (1981). Relationship between sporulation medium and germination ability of Mucor racemosus sporangiospores. Journal of General Microbiology 127, 35-43.

TripP, M. L. \& PAZNoKAs, J. L. (1982). Glucoseinitiated germination of Mucor racemosus sporangiospores. Journal of General Microbiology $128,477-483$.

VARY, J. C. (1978). Glucose-initiated germination in Bacillus megaterium spores. In Spores VII, pp. 104-108. Edited by G. Chambliss \& J. C. Vary. Washington, D.C.: American Society for Microbiology.

Wertman, K. F. \& Paznokas, J. L. (1981). Effect of cyclic nucleotides on the germination of Mucor racemosus sporangiospores. Experimental Mycology (in the Press).

Woese, C. R., Vary, J. C. \& Halvorson, H. O. (1968). A kinetic model for bacterial spore germination. Proceedings of the National Academy of Sciences of the United States of America 59, 869-875.

ZonNeveld, B. J. M. (1980). Protease levels in relation to CAMP and a reserve polymer during growth and sexual differentiation of Aspergillus nidulans. Experimental Mycology 4, 140-146. 